\title{
Frequency of deletion of short arm satellites in acrocentric chromosomes
}

\author{
JOHANNES NIELSEN, URSULA FRIEDRICH, and ÁSTRÁDUR B. HREIDARSSON \\ The Cytogenetic Laboratory, Arhus State Hospital, Risskov, Denmark
}

\begin{abstract}
Summary. The frequency of deletion of short arm satellites has been examined in various populations. Four out of 2509 males in psychiatric institutions and prisons had Dps - or Gps - (1.6 per 1000), and five out of 6187 persons in the general population had Dps - or Gps - (0.8 per 1000). The difference is not significant.

The segregation rate of the chromosome with lack of short arm satellite material did not deviate from unity in the few families where such calculations were possible. There was no increase in abortions or non-disjunction in the families with an acrocentric chromosome lacking short arm satellite material.

The study indicates that the frequency of Dps - and Gps - in the population is between 0.5 and 1.0 per 1000 and that the lack of short arm satellite material is without any deleterious effect on phenotype.
\end{abstract}

Deletion short arms G or D have been described as associated with a number of different congenital abnormalities, but they have also been found in healthy normally developed persons (Migeon, 1965; De Grouchy et al, 1966; Mikkelsen, 1966/67; Neu, Leao, and Gardner, 1966; Bias and Migeon, 1967; Starkman and Shaw, 1967; Jagiello and Faiman, 1967; Brøgger, 1968; Parker et al, 1969; Yoshida and Honda, 1969; Warren and Rimoin, 1970; Kelch, Franklin, and Schmickel, 1971; Emerit et al, 1972). Several of these authors have stressed the need for studies of the frequency and distribution of deletion of short arm satellites D or G in different population groups.

The present study comprises those individuals with deletion short arm satellites in acrocentric chromosomes found among institutionalized patients as well as in studies of the general population.

\section{Material and Methods}

Chromosome examination was made on 48-hour lymphocyte cultures and stained with orcein and, in cases with chromosome aberrations, with quinacrine mustard. Dps - and Gps - indicate loss of the short arm satellite area in one of the acrocentric chromosomes.

Table I shows the different populations studied at the

Received 19 September 1973.
TABLE I

INDIVIDUALS WITH DELETION SHORT ARM SATELLITES OF ACROCENTRIC CHROMOSOMES IN PREVALENCE AND INCIDENCE STUDIES OF PREVALENCE AND INCIDENCE STUDIES
CHROMOSOME ABNORMALITIES AT THE CHROMOSOME ABNORMALITIES AT THE
CYTOGENETIC LABORATORY, RISSKOV

\begin{tabular}{|c|c|c|c|c|c|}
\hline \multirow{3}{*}{ Investigations } & \multicolumn{5}{|c|}{ Individuals } \\
\hline & \multirow[b]{2}{*}{ Total } & \multicolumn{4}{|c|}{$\begin{array}{l}\text { With Deletion Short } \\
\text { Arm Satellites }\end{array}$} \\
\hline & & D & G & Total & $\begin{array}{c}\text { Rate } \\
\text { per } \\
1000\end{array}$ \\
\hline \multirow{6}{*}{$\begin{array}{l}\text { (1) Male psychiatric patients } \\
\text { (2) Males with criminal } \\
\text { records } \\
\text { (3) Children at a psychiatric } \\
\text { hospital } \\
\text { (4) Randomly selected school } \\
\text { children } \\
\text { (5) Males at examination for } \\
\text { military service } \\
\text { (6) Consecutive liveborn } \\
\text { children }\end{array}$} & 1247 & 1 & - & 1) & \\
\hline & 1061 & 1 & 2 & $3\}$ & $1 \cdot 6$ \\
\hline & 240 & - & - & $-J$ & \\
\hline & 23 & 1 & - & 17 & \\
\hline & 1115 & - & - & $-\zeta$ & 0.8 \\
\hline & 5049 & 2 & 2 & 4 & \\
\hline Total & 8735 & 5 & 4 & 9 & 1.0 \\
\hline \multirow{2}{*}{$\begin{array}{l}\text { Newborn children (Hamerton } \\
\text { et al, 1972) } \\
\text { Newborn children (Lubs and } \\
\text { Ruddle, 1970) }\end{array}$} & 6829 & 4 & - & 4 & $0 \cdot 4$ \\
\hline & 2444 & 2 & - & 2 & $0 \cdot 8$ \\
\hline
\end{tabular}

Risskov Cytogenetic Laboratory; (1) 1247 psychiatric male patients, (2) 1061 males with criminal records, (3) 240 children at a psychiatric hospital, (4) 23 randomly selected school children, (5) 1115 males at examination 
for military service, and (6) 5049 consecutive liveborn children.

\section{Results}

Five persons with Dps - and four with Gps were found among the 8735 persons examined in the six groups studied (Table I). The frequency of Dps - was thus 0.6 per 1000 compared with 0.4 per 1000 in a study of 6829 newborn children by Hamerton et al (1972) and 0.8 per 1000 in a study of 2444 newborn children by Lubs and Ruddle (1970). The frequency of Gps - was 0.5 per 1000.

The frequency of Dps - and Gps - was 1.6 per 1000 among 2509 patients in psychiatric institutions compared with 0.8 per 1000 among 6187 persons in the general population $(P[$ Fischer $]=0.4889)$.

We were able to make analysis of quinacrine- stained preparations in seven of the nine propositi and their relatives, and we thus got information about which of the $D$ or $G$ chromosomes was deleted in these families. In four cases it was No. 13, No. 14 in one, No. 22 in one and No. 21 in one (Fig. 1). Examples of Dps - and Gps - in orcein-stained preparations are shown in Figs. 2 and 3. Good reproduction of pictures with satellites and short arms of the acrocentric chromosomes are difficult to obtain, but microscopic analysis easily determined which of the acrocentric chromosomes were lacking short arm satellites.

The Dps - and Gps - were familial in six cases (see Fig. 1), but the question of familial versus spontaneous cases could not be determined in three families.

There were other marker chromosomes in two of

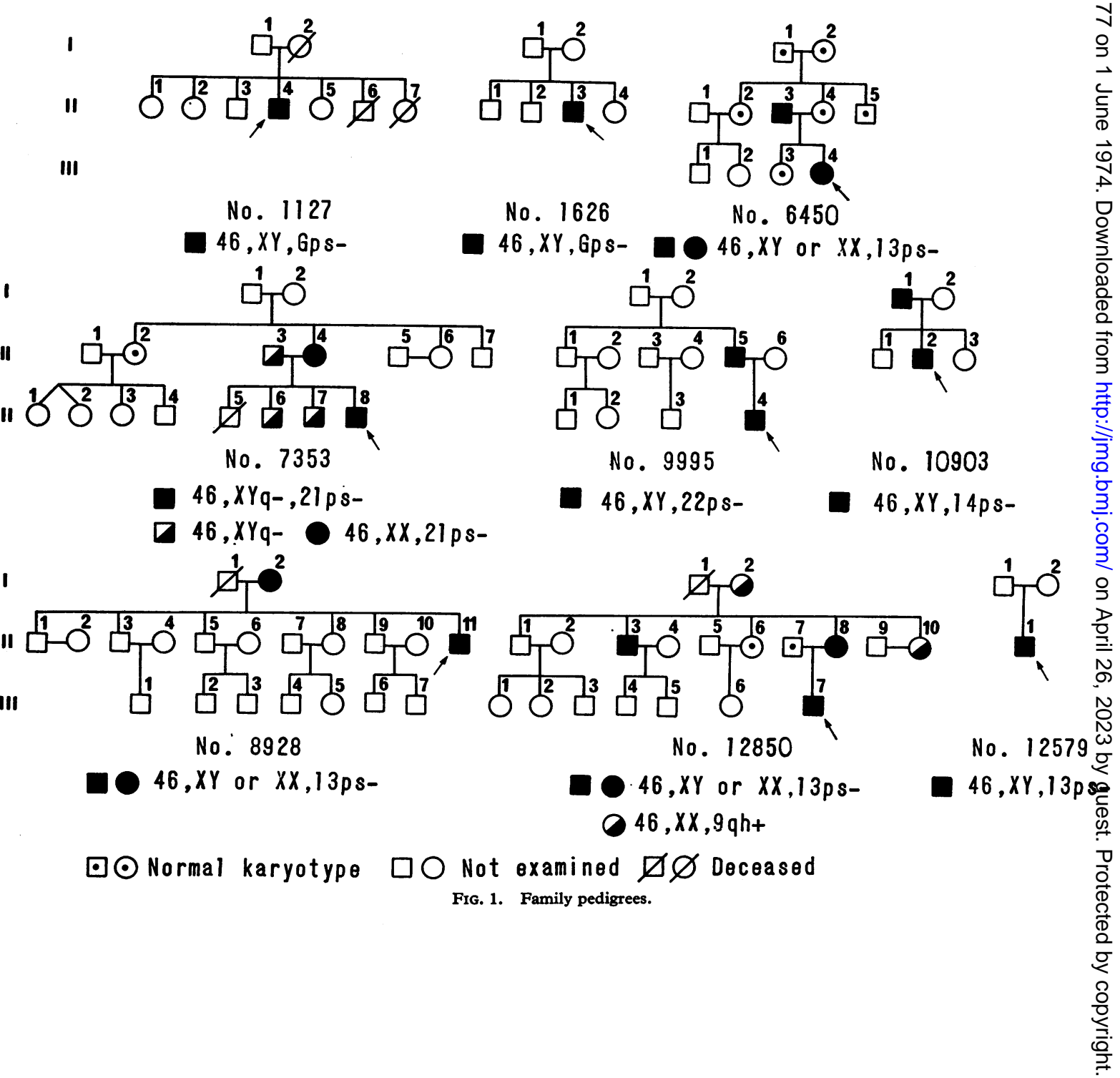


the nine families; $\mathrm{Yq}-$ in two brothers and the father of propositus No. 7353, and 9qh + in the mother of propositus No. 12850.

There was no indication of an increased risk of abortion or non-disjunction in the progeny of persons with Dps - or Gps - .

The propositi found outside institutions were all normal; those found in institutions suffered from personality deviations (Table II), but it was a common diagnosis among those examined.

There was no indication of any increased risk of physical or mental disorders among relatives of the propositi.

We did not succeed in making cytogenetic examinations in sufficient relatives of the propositi found in institutions to make a more specific comparison between relatives with and without marker chromosomes, but there was no indication of any association between the marker chromosome and any special type of mental or physical illness.

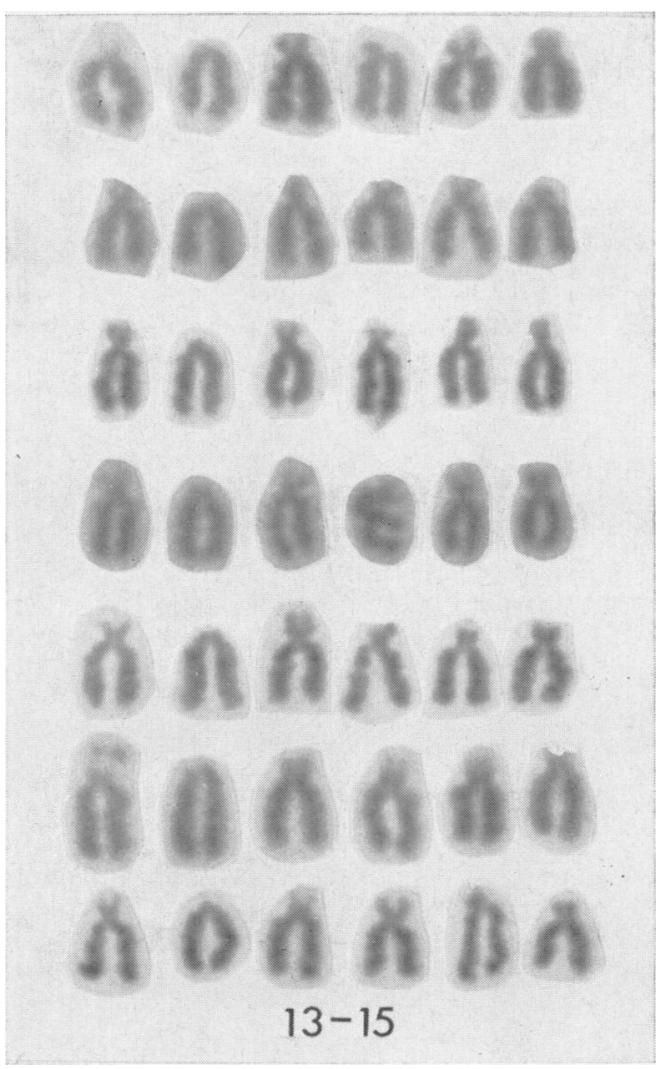

FIG. 2. Orcein-stained D chromosomes from propositi and relatives with Dps -
TABLE II

INDIVIDUALS WITH Gps - AND Dps - FOUND IN SIX STUDIES COMPRISING 8696 PERSONS

\begin{tabular}{|c|c|c|c|c|}
\hline $\begin{array}{l}\text { Investi- } \\
\text { gation }\end{array}$ & $\begin{array}{l}\text { Case } \\
\text { No. }\end{array}$ & Age & Karyotype & Comments \\
\hline 2 & 1127 & 40 & $46, X Y$, Gps - & $\begin{array}{c}\text { Personality } \\
\text { deviation; } \\
\text { borderline } \\
\text { intelligence } \\
\text { (IQ }=75) ; \\
\text { criminality }\end{array}$ \\
\hline 2 & 1626 & 20 & 46,XY,Gps - & $\begin{array}{c}\text { Personality } \\
\text { deviation; } \\
\text { criminality }\end{array}$ \\
\hline 6 & 6450 & $\begin{array}{l}\text { New- } \\
\text { born }\end{array}$ & $\begin{array}{c}46, \mathrm{XX}, 13 \mathrm{ps}- \\
16 \mathrm{qh}+\end{array}$ & $\begin{array}{c}\text { Normally } \\
\text { developed }\end{array}$ \\
\hline 6 & 7373 & $\begin{array}{l}\text { New- } \\
\text { born }\end{array}$ & $46, X Y q-, 21 p s-$ & $\begin{array}{c}\text { Normally } \\
\text { developed }\end{array}$ \\
\hline 6 & 9995 & $\begin{array}{l}\text { New- } \\
\text { born }\end{array}$ & $46, X Y, 22 p s-$ & $\begin{array}{l}\text { Normally } \\
\text { developed }\end{array}$ \\
\hline 2 & 8928 & 23 & $46, X Y, 13 p s-$ & $\begin{array}{l}\text { Personality } \\
\text { deviation; } \\
\text { criminality }\end{array}$ \\
\hline $\begin{array}{l}4 \\
1\end{array}$ & $\begin{array}{l}12579 \\
10903\end{array}$ & $\begin{array}{l}13 \\
17\end{array}$ & $\begin{array}{l}\text { 46,XY,13ps - } \\
46, X Y, 14 p s-\end{array}$ & $\begin{array}{l}\text { Normal } \\
\text { Personality } \\
\text { deviation }\end{array}$ \\
\hline 6 & 12850 & $\begin{array}{l}\text { New- } \\
\text { born }\end{array}$ & $46, \mathrm{XY}, 13 \mathrm{ps}-$ & $\begin{array}{c}\text { Normally } \\
\text { developed }\end{array}$ \\
\hline
\end{tabular}

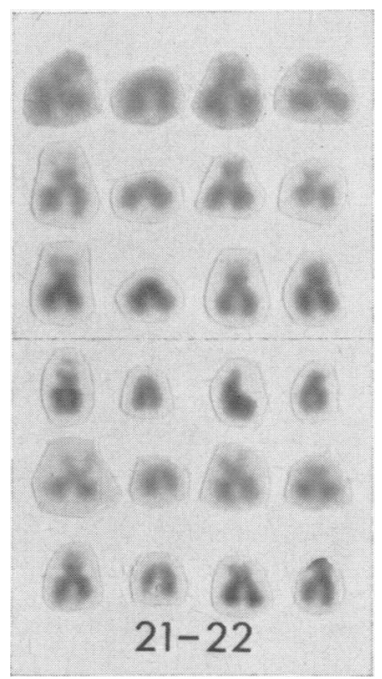

Fig. 3. Orcein-stained $\mathrm{G}$ chromosomes from propositi and relatives with Gps -

\section{Discussion}

The frequency of Dps - and Gps - in the general population lies most probably between 0.5 and 1.0 per 1000 calculated from the present study as well as from the study by Hamerton et al (1972).

The frequency of Dps - and Gps - was higher among individuals found in institutions compared with those from the general population, but the difference was not significant, and our family studies 
did not indicate that Dps - and Gps - were associated with any special mental or physical disorders.

The number of relatives examined was small, but the segregation rate did not appear to deviate significantly from unity with four out of seven relatives at risk carrying the deletion short arm satellite material. This correlates with our findings of $14 \mathrm{ps}$ - in 12 of the 23 relatives at risk (52\%) in a family with this aberration (Nielsen et al, 1973).

Quinacrine-stained preparations were made in all five cases with Dps - , four of whom had 13ps - and one $14 \mathrm{ps}$ - . Two of the four Gps - were analysed with quinacrine stain. They had 22ps - and 21ps -, respectively, but no conclusions can be drawn concerning the question of random distribution of deletion short arm satellites in D and G chromosomes.

\section{REFERENCES}

Bias, W. B. and Migeon, B. R. (1967). Haptoglobin: a locus on the $\mathrm{D}_{1}$ chromosome ? American fournal of Human Genetics, 19, 393398.

Brøgger, A. (1968). Exclusion of marker genes from the short arm of the human chromosome $\mathrm{D}_{1}$ by deletion mapping. Hereditas, Genetiskt Arkiv, 62, 116-130.

De Grouchy, J., Salmon, C., Salmon, D., and Maroteaux, P. (1966). Délétion du bras court d'un chromosome 13-15, hypertélorisme et phénotype haptoglobine $\mathrm{HpO}$ dans une même famille. Annales de Génétique, $9,80-85$.
Emerit, I., Noel B., Thiriet, M., Loubon, M., and Quack, B. (1972). Short arm deletion of chromosome 14. Humangenetik, 15, 33-38.

Hamerton, J. L., Ray, M., Abbott, J., Williamson, C., and Ducasse, G. C. (1972). Chromosome studies in a neonatal population. Canadian Medical Association fournal, 106, 776-779.

Jagiello, G. and Faiman, C. (1967). Unilateral fixation of the ossicular chain associated with G-group chromosome deletion. Canadian Medical Association fournal, 96, 1405-1407.

Kelch, R. P., Franklin, M., and Schmickel, R. D. (1971). Group G deletion syndromes. Fournal of Medical Genetics, 8, 341-345.

Lubs, H. A. and Ruddle, F. H. (1970). Applications of quantitative karyotypy to chromosome variation in $\mathbf{4 4 0 0}$ consecutive newborns. In Human Population Cytogenetics, ed. by P. A. Jacobs, W. H. Price, and P. Law, pp. 120-142. University Press, Edinburgh.

Migeon, B. R. (1965). Familial variant autosomes: new human cytogenetic markers. Bulletin of the fohns Hopkins Hospital, 116, 396-402.

Mikkelsen, M. (1966/1967). Familial Down's syndrome. Annals of Human Genetics, 30, 125-146.

Neu, R. L., Leao, J. C., and Gardner, L. I. (1966). Short-arm deletions in G-group chromosomes. Lancet, 2, 390-391.

Nielsen, J., Friedrich, U., Hreidarsson, A. B., Petersen, G. B., and Holm, V. (1973). A family with 14p-. (In press.)

Parker, C. E., Koch, R., Mavalwala, J., Derencsenyi, A., and Hatashita, A. (1969). Familial deletion of the short arm of the $\mathrm{D}_{1}$-chromosome $(46, \mathrm{XX}, 13 \mathrm{p}-)$ not associated with loss of haptoglobin or catalase activity. Clinical Pediatrics, 8, 453-458.

Starkman, M. N. and Shaw, M. W. (1967). Atypical acrocentric chromosomes in negro and Caucasian mongols. American fournal of Human Genetics, 19, 162-173.

Warren, R. J. and Rimoin, D. L. (1970). The G deletion syndromes. Fournal of Pediatrics, 77, 658-663.

Yoshida, M. C. and Honda, T. (1969). Familial occurrence of a short arm deletion of a G-group chromosome. Fapanese fournal of Human Genetics, 14, 140-144. 